\title{
SW-620 cells treated with topoisomerase I inhibitor SN-38: gene
} expression profiling

\author{
Vinicius Souza ${ }^{1}$, Yan Bin Dong ${ }^{1}$, H Sam Zhou ${ }^{2,3}$, Wolfgang Zacharias ${ }^{2}$ and \\ Kelly M McMasters*1,3
}

Address: ${ }^{1}$ Division of Surgical Oncology, Department of Surgery, University of Louisville School of Medicine, Louisville, Kentucky, USA, 2Department of Medical Oncology, University of Louisville School of Medicine, Louisville, Kentucky, USA and ${ }^{3}$ James Graham Brown Cancer Center, Louisville, Kentucky, USA

Email: Vinicius Souza - vinniesouza@hotmail.com; Yan Bin Dong - d0yanb01@louisville.edu; H Sam Zhou - hszhou01@louisville.edu; Wolfgang Zacharias -w0zach01@louisville.edu; Kelly M McMasters* - kelly.mcmasters@nortonhealthcare.org

* Corresponding author

Published: 23 December 2005

Journal of Translational Medicine 2005, 3:44 doi:10.1 I86/1479-5876-3-44
Received: 23 August 2005

Accepted: 23 December 2005

This article is available from: http://www.translational-medicine.com/content/3/I/44

(c) 2005 Souza et al; licensee BioMed Central Ltd.

This is an Open Access article distributed under the terms of the Creative Commons Attribution License (http://creativecommons.org/licenses/by/2.0), which permits unrestricted use, distribution, and reproduction in any medium, provided the original work is properly cited.

\begin{abstract}
Background: The goal of this study was to evaluate changes in gene expression in SW-620 cells in response to $\mathrm{SN}-38$ in order to further elucidate the mechanisms by which $\mathrm{SN}-38$ causes apoptosis and cell cycle arrest.
\end{abstract}

Methods: We used a quantitative gene expression microarray assay to identify the genes regulated by SN-38 treatment in colon cancer cells and confirmed our results with RT-PCR. By gene expression profiling, we first screened a proprietary list of about 22,000 genes.

Results: Treatment with SN-38 cells resulted in two-fold or greater alteration in the level of expression of 192 genes compared to control treatment. Most of the affected genes were not known to be responsive to $\mathrm{SN}-38$ prior to this study. SN-38 treatment of these cells was found to affect the expression of various genes involved in DNA replication, transcription, signal transduction, growth factors, cell cycle regulation, and apoptosis, as well as other genes with unknown function. Changes in expression of 14 genes were confirmed by quantitative real-time polymerase chain reaction (RT-PCR).

Conclusion: This study leads to an increased understanding of the biochemical pathways involved in $\mathrm{SN}$-38-induced apoptosis and possibly to the identification of new therapeutic targets.

\section{Introduction}

Each year over 50,000 people in the United States die from colorectal cancer, which is the second leading cause of cancer death [1]. Although the mortality rate associated with colorectal cancer has been declining, in part due to early diagnosis and the introduction of new drugs, present therapy is often ineffective. Moreover, the majority of the colorectal cancer cases that are known to be hereditary do not show a clearly identifiable genetic etiology [2].

Irinotecan (CPT-11) is a chemotherapeutic prodrug that is converted to SN-38 (its most active metabolite) by carboxylesterases that are abundantly present in the liver [3]. SN38 has high anti-tumor activity against refractory solid tumors, such as carcinomas of the lung, cervix, ovary, and 
colon [4]. SN-38 binds the transient cleavable complex between DNA and topoisomerase I, preventing dissociation of the DNA-topoisomerase I complex and thereby inducing cell cycle arrest and apoptosis. This mechanism of action of SN-38 was observed in colon cancer cell lines [5]. Topoisomerase I functions to unwind portions of the DNA during replication and transcription by making transient nicks followed by re-ligation in one strand of the DNA. SN-38 works to prevent topoisomerase I from resealing these DNA nicks. As replication continues, permanent single strand breaks in the DNA lead to cell death [6]. SN-38 effectiveness has been directly linked to high levels of topoisomerase I activity in the cell [7]. Since the activity of topoisomerase I is usually higher in the tumor cells than in normal cells, SN-38 action holds some degree of specificity to tumor cells [6]. Furthermore, a decrease in expression levels of topoisomerase I in colorectal cancer cell lines is believed to cause resistance against the effects of SN-38. In the present study, we investigated the changes in gene expression that accompany SN-38induced colorectal cancer cell apoptosis to evaluate possible novel signaling pathways involved in this process.

\section{Materials and methods Cells and culture conditions}

Human colon cancer cell line SW-620 was purchased from ATCC (Rockville, MD; ATCC number CCL-227). Cells were routinely propagated as a monolayer culture in Dubbelco's Modified Eagle Medium (Gibco, Invitrogen) supplemented with $10 \%$ heat-inactivated fetal bovine serum (FBS) and penicillin $(100 \mathrm{U} / \mathrm{ml}) /$ streptomycin $(100 \mu \mathrm{g} / \mathrm{ml})$ solution. All cell culture reagents were obtained from Invitrogen/Life Technologies (Carlsbad, CA). SN-38 was purchased from Sigma (St. Louis, MO). Cells were cultured in a $5 \% \mathrm{CO}_{2}$ incubator at $37^{\circ} \mathrm{C}$ and sub-cultured every 3 to 4 days (when about $80 \%$ confluent).

For experiments, SW-620 cells were plated for $48 \mathrm{~h}$ in $4 \times$ 6 -well plates $\left(3 \times 10^{5}\right.$ cells/ well $)$. Cells were then exposed to SN-38 (50 nM concentration) for $18 \mathrm{~h}$. The control sample was exposed to vehicle only. For further control of the effects of SN-38, SW-620 cells were also plated in $1 \times$ 96-well plate $\left(1 \times 10^{4} \mathrm{cells} /\right.$ well $)$ for $48 \mathrm{~h}$. Cells were then exposed to increasing concentrations of SN-38 $(0,12.5$ $\mathrm{nM}, 25 \mathrm{nM}, 50 \mathrm{nM}, 100 \mathrm{nM}, 200 \mathrm{nM}$ ) and samples were analyzed after $18 \mathrm{~h}, 92 \mathrm{~h}, 120 \mathrm{~h}$, and $168 \mathrm{~h}$.

\section{Microarray analysis}

\section{CRNA synthesis and labeling}

At $18 \mathrm{~h}$ after drug exposure, total RNA was isolated with Trizol reagent (Gibco Life Technologies). We chose a time point prior to any evidence of apoptosis because we wanted to investigate the persistent changes in gene expression in response to $\mathrm{SN}-38$ treatment. First- and sec- ond-strand cDNA were synthesized from 5-15 $\mu$ g of total RNA using the SuperScript Double-Stranded cDNA Synthesis Kit (Gibco Life Technologies) and oligo-dT24-T7 (5'-GGC CAG TGA ATT GTA ATA CGA CTC ACT ATA GGG AGG CGG-3') primer, according to the manufacturer's instructions.

Next, cRNA was synthesized and labeled with biotinylated UTP and CTP by in vitro transcription using the T7 promoter coupled double-stranded cDNA as template and the T7 RNA Transcript Labeling Kit (ENZO Diagnostics Inc.). Briefly, ds cDNA synthesized from the previous steps were washed twice with $70 \%$ ethanol and resuspended in $22 \mu \mathrm{l}$ of RNase-free $\mathrm{H}_{2} \mathrm{O}$. The cDNA was incubated with $4 \mu \mathrm{l}$ of $10 \times$ each reaction buffer, biotin-labeled ribonucleotides, DTT, RNAse inhibitor mix and $2 \mu \mathrm{l} 20 \times$ T7 RNA polymerase for $5 \mathrm{~h}$ at $37^{\circ} \mathrm{C}$. The labeled cRNA was separated from unincorporated ribonucleotides by passing through a CHROMA SPIN-100 column (Clontech) and precipitated at $-20^{\circ} \mathrm{C}$ for $1 \mathrm{~h}$ to overnight.

\section{Oligonucleotide array hybridization and analysis}

The cRNA pellet was resuspended in $10 \mathrm{ul}$ RNase-free $\mathrm{H}_{2} \mathrm{O}$, and $10.0 \mu \mathrm{g}$ was fragmented by heat and ion-mediated hydrolysis at $95^{\circ} \mathrm{C}$ for $35 \mathrm{~min}$ in $200 \mathrm{mM}$ Tris-acetate, $\mathrm{pH} 8.1,500 \mathrm{mM} \mathrm{KOAc}$, and $150 \mathrm{mM} \mathrm{MgOAc}$. The fragmented cRNA was hybridized for $16 \mathrm{~h}$ at $45^{\circ} \mathrm{C}$ to HG_U95Av2 oligonucleotide arrays (Affymetrix, Santa Clara, CA) containing 22,284 gene transcripts together with additional probe sets designed to represent EST sequences. Arrays were washed at $25^{\circ} \mathrm{C}$ with $6 \times \operatorname{SSPE}(0.9$ $\mathrm{M} \mathrm{NaCl}, 60 \mathrm{mM} \mathrm{NaH} \mathrm{PO}_{4}, 6 \mathrm{mM}$ EDTA $+0.01 \%$ Tween 20) followed by a stringent wash at $50^{\circ} \mathrm{C}$ with $100 \mathrm{mM}$ MES, $0.1 \mathrm{M}[\mathrm{Na}+]$, and $0.01 \%$ Tween 20 . The arrays were then stained with phycoerythrein-conjugated streptavidin (Molecular Probes), and the fluorescence intensities were determined using a laser confocal genearray scanner (Agilent). The scanned images were analyzed using Microarray Suite 5.0 or GCOS software (Affymetrix). Sample loading and variations in staining were standardized by scaling the average of the fluorescent intensities of all genes on an array to constant target intensity (250) for all arrays used. Data analysis was conducted using Microarray Suite 5.0 (Affymetrix) following user guidelines. The signal intensity for each gene was calculated as the average intensity difference, represented by $[\Sigma(P M-M M) /($ number of probe pairs)], where PM and MM denote perfect-match and mismatch probes. Several criteria were used to identify genes whose expression was affected by SN-38 treatment. First, whether the fold-change of each gene, as provided by the Affymetrics analysis, was more than 2fold up- or down-regulation. The second criterion employed was whether the difference call, as provided by the GeneChip software was moderately induced (MI) or induced (I) for upregulated genes and moderately 
decreased (MD) or decreased (D) for downregulated genes. In addition, only genes in which absolute calls were double present (or one present - one absent in SN-38 versus control) were considered as $\mathrm{SN}-38$ responsive genes. Two completely independent experiments were performed. Only genes that had changed in the same direction in both experiments with the change $\mathrm{p}$ value of $<$ 0.006 were considered for further analysis. The final fold changes were calculated based on the average signal log ratio of the two experiments. The genes whose average expression differed by more than 2-, 5- or 10 -fold when compared to the control treatment were grouped by functional category.

We used the on-line data mining tools from 3 different software programs: NetAffx Analysis Center (Affymetrix, Santa Clara, CA), GeneSpring (Silicon Genetics, Redwood City, CA), and Genesifter (VizX Labs, Seattle, WA).

\section{RT-PCR}

At $18 \mathrm{~h}$ after drug exposure, RNA was prepared using the RNeasy mini kit along with RNase-free DNase set to rid any traces of DNA contamination (both kits were from QIAGEN, Valencia, CA). cDNA was prepared from $500 \mathrm{ng}$ of RNA (TaqMan Reverse Transcription Reagents, ABI/ Roche, Branchburg, NJ), based on the manufacturer's instructions. The template cDNA (12.5 ng/sample) for control and SN-38 was mixed with Syber green master mix (ABI). Mixtures were aliquoted into 96-well optical reaction plates $(\mathrm{ABI})$ along with forward and reverse primers for each target gene. Samples were run in duplicates. The ABI Prism 7000 sequence detection system was used. Primers were designed using ABI primer express software. Amplicon sizes were all below $200 \mathrm{bp}$. Data were analyzed using the comparative $C_{\mathrm{T}}$ method, which the fold change of target gene samples (SN-38 treatment) normalized to the housekeeping gene (beta-actin) relative to the calibrator (control) is calculated by $2^{-\Delta \Delta C T}$ equation, where $\Delta \Delta C_{\mathrm{T}}$ $=\Delta C_{\mathrm{T}}$ (sample) $-\Delta C_{\mathrm{T}}$ (calibrator), and $\Delta C_{\mathrm{T}}$ is the $C_{\mathrm{T}}$ value of the target gene subtracted from the $C_{\mathrm{T}}$ value of the housekeeping gene, all determined in the exponential phase of the reactions [8]. (PCR primers are listed in Table $1)$.

\section{Trypan blue cell count and cell cycle analysis}

At $18 \mathrm{~h}$ after drug exposure, cells from two wells of each treatment were harvested, and half of them were stained with trypan blue solution $0.4 \%$ (Sigma Chemical Co.) for $5 \mathrm{~min}$. Cells from each of the samples then were counted using a hemacytometer. The other half of each of the two samples was washed once with PBS and fixed in $70 \%$ (vol/ vol) ethanol at $-20^{\circ} \mathrm{C}$ for up to one week. Cells were pelleted, washed once with PBS, and resuspended in propidium iodide (PI) solution $(50 \mu \mathrm{g} / \mathrm{ml} \mathrm{PI}, 0.5 \mathrm{mg} / \mathrm{ml}$ RNase in PBS, $\mathrm{pH}$ 7.4) for $30 \mathrm{~min}$ in the dark. Flow cytometry analysis was performed at $18 \mathrm{~h}$ after treatment. FACS analysis was performed on a FACScan flow cytometer (Becton Dickinson, San Jose, CA, USA). The data from 10,000 cells were collected and analyzed using CellFIT cell-cycle analysis software (version 2.01.2).

\section{MTT assay}

The MTT assay is also used for the measurement of cytotoxicity of a drug. Briefly, SW-620 cells were plated into 96-well plates and treated with increasing concentration of SN-38 (0 nM, $12.5 \mathrm{nM}, 25 \mathrm{nM}, 50 \mathrm{nM}, 100 \mathrm{nM}, 200$ $\mathrm{nM})$. We used 1e4 cells in $100 \mu \mathrm{l}$ of DMEM 10\%FBS per well. After $18 \mathrm{~h}, 24 \mathrm{~h}, 96 \mathrm{~h}$, and $120 \mathrm{~h}$ of incubation at $37^{\circ} \mathrm{C}, 10 \mu \mathrm{l}$ MTT ( $5 \mathrm{mg} / \mathrm{ml}$, Sigma, St. Louis, MO) was added to each well and incubated at $37^{\circ} \mathrm{C}$ for $4 \mathrm{~h}$. After incubation, $50 \mu \mathrm{l}$ lysing buffer $(10 \%$ SDS in $0.01 \mathrm{~N} \mathrm{HCl})$ was added, and samples were incubated at $37^{\circ} \mathrm{C}$ overnight for complete cell lysis. On the following day, cytotoxicity was assessed by measuring the conversion of the tetrazolium salt MTT to formazan through measurement of absorbance at $570 \mathrm{~nm}$.

\section{Results \\ Exposure to SN-38 alters the gene expression in SW-620 colon cancer cells}

At $18 \mathrm{~h}$ after treatment, flow cytometry analysis demonstrated no significant change in G2 cell cycle arrest between treatment and control. At the same time point, MTT analysis did not demonstrate any significant difference in cell viability. After 4 days, MTT analysis showed a $30 \%$ decrease in cell proliferation in treated cells compared to the control. Our results are consistent with past studies that showed SN-38 induces apoptosis in cells with dysfunctional $p 53$ gene (SW-620 cells are $p 53$ mutant) $[6,9]$.

In our microarray analysis, after $18 \mathrm{~h}$ of $\mathrm{SN}-38$ exposure, 192 genes demonstrated over a 2 -fold change in mRNA expression. Forty of these 192 genes were downregulated, whereas 152 genes were upregulated. Among those genes, we found 13 genes with expression change greater than 5fold: 10 upregulated and 3 downregulated. Next, we used NetAffx analysis to categorize all of the altered genes based on their biological processes and molecular functions, and we found most of the genes to be related to transcription, DNA replication, signal transduction, growth factors, cell cycle regulation, and apoptosis. All but one of the genes related to apoptosis and DNA replication were upregulated (FAF1 was downregulated).

Little variation was observed in the 840 genes that changed in both microarray experiments (Fig. 1). We found 192 genes that had altered expression over 2-fold and changed in the same direction and with similar fold changes. In addition, genes that had more than one set of 


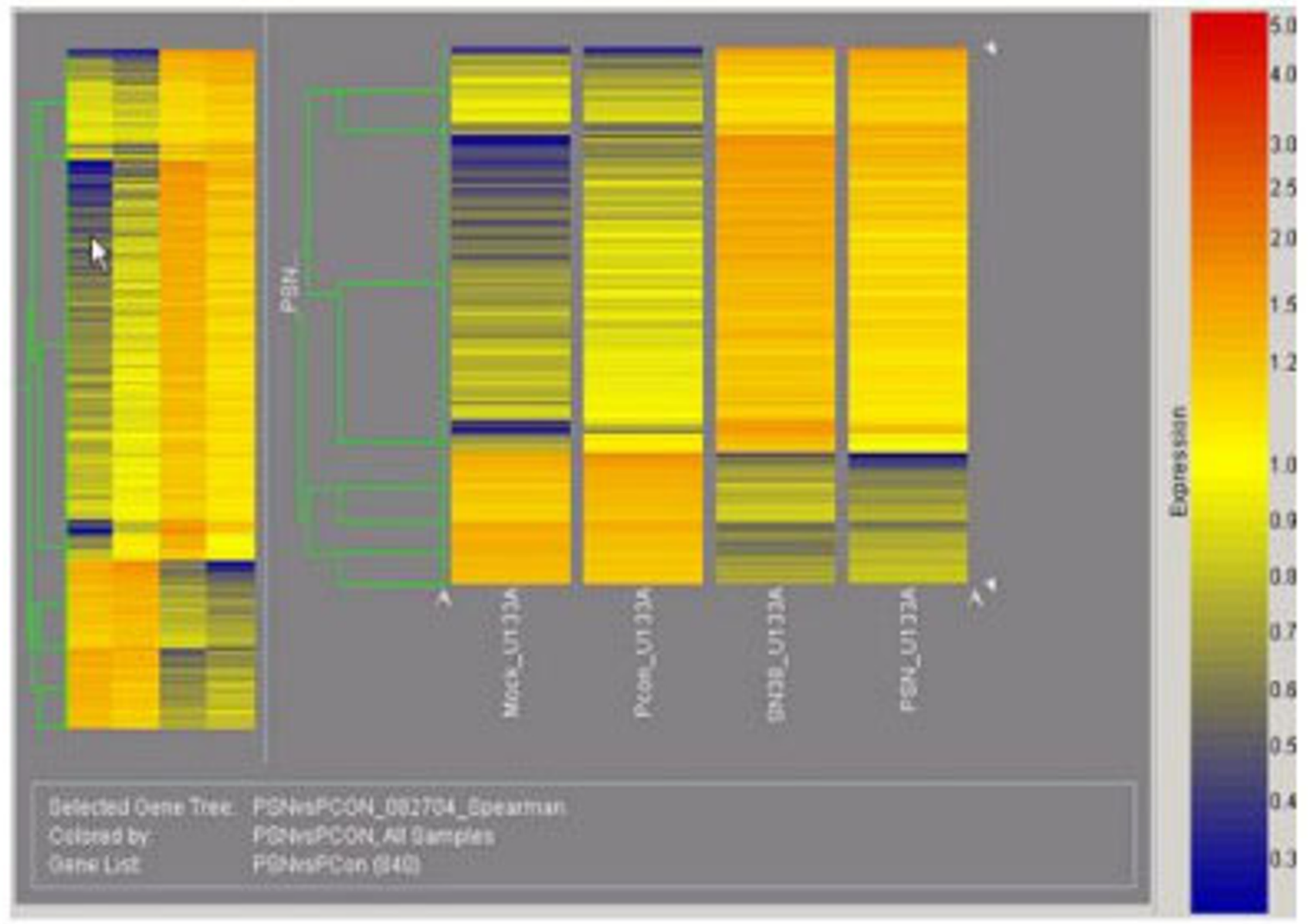

\section{Figure I}

The two independent microarray experiments behaved similarly: Genes demonstrated in this gene tree contain 840 genes that changed with a $p$ value $<0.006$ in either experiment, indicating whether the genes in the two experiments were upregulated or downregulated in the same direction in both experiments. GeneSpring software (version 6.I) was used for this gene tree (Silicon Genetics, Redwood City, CA). Values below 0.01 were set to 0.01 . Each measurement was divided by the 50 th percentile of all measurements in that sample. Each measurement for each gene in the specific samples was divided by the median of that gene's measurements in the corresponding control samples. (A full description of these genes and detail of analysis is available on the GEO repository web site, attachment to Acc. \#GSM24425-28). Mock and Pcon are the control sample for experiment I and experiment 2, respectively. SN-38 and PSN are the treatment sample for experiment I and 2, respectively.

probes represented in the microarray chip had the same expression pattern. We used Miroarray Suite 5 (MAS 5), Data Mining Tool (DMT), and NetAffx Analysis Center to categorize the genes according to their biological and molecular functions. The vast majority of the genes fell into four categories: cell cycle, apoptosis, signal transduction, and transcription.

\section{Verification of microarray analysis by quantitative RT-PCR} RT-PCR was performed to confirm the changes in gene expression observed in the microarray analysis. RNA samples from all three treatments in each of the two experi- ments were used to confirm changes. We selected genes that either had a high fold change in both microarray experiments or were directly related to apoptotic pathways and cell cycle regulation. For all 14 genes tested, results from microarray and RT-PCR were in agreement (primers are listed in Table 1). Some genes that had a high fold change in only one microarray experiment were also tested. For each of these genes, no change was observed on RT-PCR. 
Table I: Verification of microarray analysis by Real Time - Polymerase Chain Reaction: In order to evaluate the SN-38-mediated activation of pro-apoptotic pathways, we confirmed the microarray results with real-time PCR using total RNA from $18 \mathrm{~h}$ post SN-38 exposure of the SW-620 cells and control. Primer express software from ABI has been used to design the primers for real-time PCR (amplicon sizes were about 70 bp). Gene symbols and Probe Set ID numbers are as found at the NCBI website http://www.ncbi.nlm.nih.gov and NetAffx ${ }^{\mathrm{TM}}$ Analysis Center http://www.affymetrix.com/analysis/index.affx. Data are averages from two separate experiments, each in duplicate. Data are reported as the fold change of gene expression level SN-38 treated cells versus no treatment control. FC $=$ fold change.

\begin{tabular}{|c|c|c|c|c|}
\hline Gene Symbol & Affymetrix Probe Set ID & Primer for RT-PCR & RT-PCR avg. FC & Microarray avg. FC \\
\hline$\beta$-actin & NM_00II0I & $\begin{array}{l}\text { F: CGATCCACACGGAGTACTTG } \\
\text { R: GGATGCAGAAGGAGATCACTG }\end{array}$ & NC & NC \\
\hline RGC32 & 218723_s_at & $\begin{array}{l}\text { F: GAAGCCTTCATTGCTGATCTTG } \\
\text { R: GTCCTCGGAACTTTCTGAAGCT }\end{array}$ & 6.2 & 6.5 \\
\hline ITGB7 & 2057/8_at & $\begin{array}{l}\text { F: CGGCTCTCGGTGGAAATCTAT } \\
\text { R: GGTCGTGATGGCACTTTTGTAG }\end{array}$ & 3.1 & 7.8 \\
\hline PDCD4 & 202731_at & $\begin{array}{l}\text { F: GTGCTGGAGCGGTTTGTAGAA } \\
\text { R: CCTTCGCTTACAAAACGCTTTC }\end{array}$ & 1.8 & 2.5 \\
\hline ABAT & 209459_s_at & $\begin{array}{l}\text { F: CTGTTGGTTCAACGTGGTTTCC } \\
\text { R: GCATTTCGGTATCATCTGCCTG }\end{array}$ & 3.4 & 6.7 \\
\hline DKK3 & 214247_s_at & $\begin{array}{l}\text { F: ACCCCTGTCCAGATTATTGGC } \\
\text { R: TTGTTTCCATCTCCTCCCCTC }\end{array}$ & 4.4 & 6 \\
\hline LYZ & 213975_s_at & $\begin{array}{l}\text { F: CGCTACTGGTGTAATGATGGCA } \\
\text { R: CAAGCTACAGCATCAGCGATGT }\end{array}$ & 4.6 & 11 \\
\hline CCL20 & 205476_at & $\begin{array}{l}\text { F: GTCTGTGTGCGCAAATCCAA } \\
\text { R: CCATTCCAGAAAAGCCACAGTT }\end{array}$ & 3.6 & 10.6 \\
\hline UBD & 205890_s_at & $\begin{array}{l}\text { F: TTGCAATGGAAAGAGACTGGAA } \\
\text { R: AGGAAGAGTAAGTTGCCCTTTCTG }\end{array}$ & 28.2 & 17.9 \\
\hline FGF3 & 21457I_at & $\begin{array}{l}\text { F: AATCAGGGTCCAGTGGGAACT } \\
\text { R: CAAATGCCCTGCATTGCA }\end{array}$ & -12.6 & -5.1 \\
\hline FAFI & 218080_x_at & $\begin{array}{l}\text { F: CGGTGGAACCAGCCATTC } \\
\text { R: TTGGCGAGGAGCCCTTCT }\end{array}$ & -4.8 & -5.1 \\
\hline HISTIH2BK & 208527_x_at & $\begin{array}{l}\text { F:TACGTGTACAAGGTGCTGAAACAG } \\
\text { R: CATGATCCCCATGGCTTTAGA }\end{array}$ & -8.6 & -6.1 \\
\hline Cyclin EI & 213523_at & $\begin{array}{l}\text { F: CACCAGCCACCTCCAGACA } \\
\text { R: GTGGGAGTCCCTTAGGTCAACTAG }\end{array}$ & 3.1 & 2.2 \\
\hline Cyclin E2 & 205034_at & $\begin{array}{l}\text { F:GAAGTAGCCGTTTACAAGCTAAGCA } \\
\text { R: GCCTGGATTATCTGGGCTTCT }\end{array}$ & 3.2 & 4.1 \\
\hline TNFRSF6 & 216252_x_at & $\begin{array}{l}\text { F: AATCATCAAGGAATGCACACTCA } \\
\text { R: AAGCCACCCCAAGTTAGATCTG }\end{array}$ & 4.2 & 4.5 \\
\hline
\end{tabular}

\section{Genes involved in apoptotic pathways}

Several genes directly involved in apoptotic pathways were significantly altered. Different isoforms of the TNFRSF6 gene [tumor necrosis factor (TNF) receptor] were found to be upregulated. This result is in agreement with suggestions that SN-38 increases sensitivity of the cells to TNF-related apoptosis-inducing ligand (TRAIL) [10]. Other studies detected upregulation of several genes in the TNF family as early as $2 \mathrm{~h}$ after exposure to SN-38 [11]. This indicates that changes in the expression of TNFrelated genes are persistent, and these changes may play an essential role in induction of apoptosis. Intriguingly, we found that Fas associated factor-1 (FAF-1), a Fas-binding pro-apoptotic protein, was downregulated, suggesting that it does not play a direct role in apoptosis induced by SN-38 [12-14]. It has been shown that Bax activation, a pro-apoptotic member of the $\mathrm{Bcl}-2$ family, is required for TRAIL-mediated apoptosis in colon cancer cells (HCT116) [15-17]. Other studies have also demonstrated Bax upregulation after SN-38 treatment in colorectal can- cer cells [18]. In conformity to these studies, we found that Bax expression was 2.5-fold upregulated in our experiment. In addition, BNIP3L, a homolog of the pro-apoptotic protein BNIP3, was slightly upregulated. Overexpression of both BNIP3L and Bax suggest that SN38 may act via the Bax-related apoptotic pathway.

\section{Discussion}

Our results showed an increase in expression of three genes in the cyclin family: Cyclin E1 (CCNE1), Cyclin E2 (CCNE2), and Cyclin G2 (CCNG2). Cyclins are involved in cell cycle regulation and tumor growth. Previously, Ueno et al. [19] demonstrated Cyclin E expression is enhanced after colorectal cancer cells are exposed to $\mathrm{SN}$ 38 and suggested that upregulation of Cyclin E expression might trigger induction of apoptosis. Our results also showed a mild upregulation in a variety of cyclin-dependent kinase (Cdk)-related genes, and significant overexpression of $R G C 32$, that encodes a protein involved in the regulation of cyclin-dependent kinase activity that is 
known to increase DNA synthesis in glioma cells [20]. It has been shown that flavopiridol, a cyclin-dependent kinase inhibitor, when used in combination with SN-38, synergistically increases cell death in colon cancer cells [9]. Our findings suggest flavopiridol might enhance the apoptotic effects of SN-38 in tumor cells by inhibiting Cdk and Cdk-related gene activity. Further experiments are necessary to evaluate the role of $\mathrm{Cdk}$ in resistance to $\mathrm{SN}-38$ therapy and its importance in the regulation of colon cancer cell death.

SN-38 reduces tumor growth by inhibiting topoisomerase I function. Interestingly, studies have shown no change in the level of topoisomerase I mRNA following SN-38 treatment $[9,21]$. Our results were consistent with these studies showing that topoisomerase I mRNA upregulation by SN-38 is not necessary to achieve drug-induced apoptosis. However, we identified several other genes, not recognized in previous studies, which may be $\mathrm{SN}-38$ target candidates. We identified 13 genes with expression altered by more than 5 -fold. The gene with the highest upregulation is UBD (ubiquitin D, 17.9-fold). Although further studies are needed to investigate the role of $U B D$ in inhibiting cell growth in SN-38-treated SW620 cells, UBD expression may increase via the proteasome pathway degradation of proteins that induce cell growth. The second highest expressed gene in $\mathrm{SN}-38$ cells compared to controls is $L Y Z$ (lysozyme involved in carbohydrate metabolism) with an 11 -fold change, and third is CCL20 (a chemokine ligand) with 10.6-fold change. Previous studies have demonstrated that overexpression of chemokines (including CCL-20) in murine tumor cells can induce anti-tumor Tcell responses by recruiting immature dendritic cells $[22,23]$. Further studies are necessary to determine whether CCL-20 behaves in a similar fashion in human cancer cells. Other genes significantly upregulated were ITGB7 (involved in integrin-mediated cell adhesion), $A B A T$ (involved in metabolism, regulation of transcription and GENMAPP/KEGG pathway), DKK3 (a regulator of the Wnt receptor signaling pathway involved in development and morphogenesis), PROCR (encodes a receptor for activated protein C), SGK (involved in protein aa phosphorylation, sodium ion transport, response to stress, and apoptosis), and SMARCA1 (which is thought to regulate the transcription of other genes by interfering with chromatin structure). Lastly, HIST1H2BE, which encodes a component of histones, was downregulated 6.1-fold.

\section{Conclusion}

Our data confirm and extend the findings of other investigators and introduces several possible novel pathways to explain the mechanisms used by $\mathrm{SN}-38$ to induce cell arrest and apoptosis. SN-38-induced upregulation of cell signaling receptors may increase the tumor cells' sensitiv- ity to pro-apoptotic factors, such as TRAIL. Further studies will be necessary to elucidate the pathways by which SN38 signals cells to undergo either cell arrest or apoptosis. Elucidation of these pathways may lead to the development of new drugs to overcome tumor cell resistance to $\mathrm{SN}-38$ treatment.

\section{Abbreviations}

CPT-11, irinotecan; RT-PCR, real-time polymerase chain reaction; FBS, fetal bovine serum; PI, propidium iodide.

\section{Competing interests}

The author(s) declare that they have no competing interests.

\section{Authors' contributions}

VS carried out the gene expression profiling and drafted and submitted the manuscript. YD and HSZ participated in the design of the study. WZ participated in the microarray experiments. KMM conceived of the study and participated in its design and coordination. All authors read and approved the final manuscript.

\section{Acknowledgements}

Supported by NIH grant CA ROI90784-0IAI to KMM.

\section{References}

I. Kachele V, Hahn P, Adler G, Seufferlein T: Chemotherapy for colorectal carcinoma in the elderly. Z Gastroenterol 2004, 42: I 189-1 I 98.

2. Hisamuddin IM, Yang VW: Genetics of colorectal cancer. MedGenMed 2004, 6:I3.

3. Shingyoji M, Takiguchi $Y$, Watanabe-Uruma R, Asaka-Amano Y, Matsubara H, Kurosu K, Kasahara $Y$, Tanabe N, Tatsumi K, Kuriyama T: In vitro conversion of irinotecan to $\mathbf{S N}-\mathbf{3 8}$ in human plasma. Cancer Sci 2004, 95:537-540.

4. Chen Z, Furukawa T, Sumizawa T, Ono K, Ueda K, Seto K, Akiyama S: ATP-dependent efflux of CPT-I I and SN-38 by the multidrug resistance protein (MRP) and its inhibition by PAKI04P. Mol Pharmacol 1999, 55:921-928.

5. Azzariti A, Xu JM, Porcelli L, Paradiso A: The schedule-dependent enhanced cytotoxic activity of 7-ethyl-10-hydroxy-camptothecin (SN-38) in combination with Gefitinib (Iressa ${ }^{\mathrm{TM}}$ zd I 839). Biol Pharmacol 2004, 68: I 35-I44.

6. Magrini R, Bhonde M, Hanski M, Notter M, Scherubl $H$, Boland $R$, Zeitz M, Hanzki C: Cellular effects of CPT-I I on colon carcinoma cells: Dependence on p53 and hMLHI status. Int J Cancer 2002, I 01:23-31.

7. Boyer J, McLean E, Aroori S, Wilson P, McCulla A, Carey P, Longley $D$, Johnston $P$ : Characterization of $p 53$ wild-type and null isogenic colorectal cancer cell lines resistant to 5 -fluorouracil, oxaliplatin, and irinotecan. Clin Can Res 2004, I0:2 I 58-2 167.

8. Livak KJ, Schmittgen TD: Analysis of relative gene expression data using real-time quantitative PCR and the 2(-Delta Delta C (T)) method. Methods 200I, 25:402-408.

9. Motwani M, Jung C, Sirotnak F, She Y, Shah MA, Gonen M, Schwartz $\mathrm{G}$ : Augmentation of apoptosis and tumor regression by flavopiridol in the presence of CPT-I I in Hct I 16 colon cancer monolayers and xenografts. Clin Cancer Res 2001, 7:4209-4219.

10. Gliniak B, Le T: Tumor necrosis factor-related apoptosisinducing ligand's antitumor activity in vivo is enhanced by the chemotherapeutic agent CPT-II. Cancer Res 1999, 59:6153-6158.

II. Minderman H, Conroy JM, O'Loughlin KL, McQuaid D, Quinn P, Li S, Pendyala L, Nowak NJ, Baer MR: In vitro and in vivo irinotecaninduced changes in expression profiles of cell cycle and apop- 
tosis-associated genes in acute myeloid leukemia cells. Mol Cancer Ther 2005, 4:885-900.

12. Bjorling-Poulsen M, Seitz G, Guerra B, Issinger OG: The pro-apoptotic FAS-associated factor $I$ is specifically reduced in human gastric carcinomas. Int J Oncol 2003, 4:1015-1023.

13. Chu K, Niu X, Williams LT: A Fas-associated protein factor, FAFI, potentiates Fas-mediated apoptosis. Natl Acad Sci 1995, 92:11894-11898.

14. Park MY, Hyun DJ, Soo YL, Kong-Joo L, Eunhee K: Fas-associated factor- $I$ inhibits nuclear factor- $\kappa B$ (NF- $\kappa B$ ) activity by interfering with nuclear translocation of the RelA (p65) subunit of NF-kB. J Biol Chem 2004, 279:2544-2549.

15. Griffiths GJ, Koh MY, Brunton VG, Cawthorne C, Reeves NA, Greaves M, Tilby MJ, Pearson DG, Ottley CJ, Workman P, Frame MC, Dive C: Expression of kinase-defective mutants of c-Src in human metastatic colon cancer cells decreases $\mathrm{Bcl}-\mathrm{xL}$ and increases oxaliplatin- and Fas-induced apoptosis. J Biol Chem 2004, 279:46||3-46|2|.

16. Wakahara Y, Nawa A, Okamoto T, Hayakawa A, Kikkawa F, Suganama N, Wakahara F, Tomoda Y: Combination effect of anti-Fas antibody and chemotherapeutic drugs in ovarian cancer cells in vitro. Oncology 1997, 54:48-54.

17. Wang S, El-Deiry WS: Requirement of p53 targets in chemosensitization of colonic carcinoma to death ligand therapy. Proc Natl Acad Sci USA 2003, 100:15095- 15100.

18. Hayward RL, Macpherson JS, Cummings J, Monia BP, Smyth JF, Jodrell $\mathrm{DI}$ : Antisense Bcl-xl down-regulation switches the response to topoisomerase I inhibition from senescence to apoptosis in colorectal cancer cells, enhancing global cytotoxicity. Clin Cancer Res 2003, 9:2856-2865.

19. Ueno M, Nonaka S, Yamazaki R, Deguchi N, Murai M: SN-38 induces cell cycle arrest and apoptosis in human testicular cancer. Eur Urol 2002, 42:390-397.

20. Badea TC, Niculescu FI, Soane L, Shin ML, Rus H: Molecular cloning and characterization of RGC-32, a novel gene induced by complement activation in oligodendrocytes. J Biol Chem 1998, 273:26977-2698I.

21. Goldwasser F, Bae I, Valenti M, Torres K, Pommier Y: Topoisomerase I-related parameters and camptothecin activity in the colon carcinoma cell lines from the National Cancer Institute anticancer screen. Cancer Res 1995, 55:2116-2I2I.

22. Crittenden M, Gough M, Harrington K, Olivier K, Thompson J, Vile RG: Expression of inflammatory chemokines combined with local tumor destruction enhances tumor regression and long-term immunity. Cancer Res 2003, 63:5505-50I2.

23. Okada N, Gao JQ, Sasaki A, Niwa M, Okada Y, Nakayama T, Yoshie $O$, Mizuguchi $H$, Hayakawa T, Fujita T, Yamamoto A, Tsutsumi $Y$, Mayumi T, Nakagawa S: Anti-tumor activity of chemokine is affected by both kinds of tumors and the activation state of the host's immune system: implications for chemokinebased cancer immunotherapy. Biochem Biophys Res Comm 2004, 317:68-76.

\section{Publish with Bio Med Central and every scientist can read your work free of charge}

"BioMed Central will be the most significant development for disseminating the results of biomedical research in our lifetime. "

Sir Paul Nurse, Cancer Research UK

Your research papers will be:

- available free of charge to the entire biomedical community

- peer reviewed and published immediately upon acceptance

- cited in PubMed and archived on PubMed Central

- yours - you keep the copyright

Submit your manuscript here:

http://www.biomedcentral.com/info/publishing_adv.asp
BioMedcentral 